\title{
Evaluasi Program Pendidikan dan Pelatihan Kepemimpinan Tingkat IV Pemerintah Provinsi Nusa Tenggara Barat
}

\begin{abstract}
Muslihin*
Abstract: The purpose of this research is to explain the program implementation quality and efectivity of the leadership training and education of forth level of the Government of West Nusa Tenggara Province. This research includes evaluation research program with Kirkpatrick's model (reaction, learning, behaviour, result) by using descriptive qualitative approach. Data collection instruments used were interview, observation guidelines, the study documents, and questionnaires. Data analysis using models Miles and Huberman through the display of data, data reduction, and data verification. The results showed that the participants' reactions to learning by training trainers in the category adequate with a score of $76.67 \%$, reaction training participants towards learning lectures by speakers that are in adequate category with a score of $75.17 \%$, according to the coach's ability participants with a score of $82.93 \%$, both in terms of system management and operational administration by $70.62 \%$. Participants' reactions to the energy aspects of training and education that is equal to $79.03 \%$. The effectiveness of the program in terms of the reaction of participants was on the score of 65.52 or the adequate category and questionnaire results $91.67 \%$ of participants consider the information given during the training is less practical nature.
\end{abstract}

Keywords: Program evaluation, Kirkpatrick model, leadership, training and education

\begin{abstract}
Abstrak: Tujuan penelitian ini adalah untuk menjelaskan kualitas dan efektivitas penyelenggaraan Diklat Kepemimpinan Tingkat IV pada Pemerintah Provinsi NTB. Penelitian ini termasuk jenis penelitian evaluasi program dengan model Kirkpatrick (reaction, learning, beaviour, result) dengan menggunakan pendekatan kualitatif deskriptif. Instrumen pengumpulan data yang digunakan adalah pedoman wawancara, pedoman observasi, studi dokumen, dan kuesioner. Analisis data mengunakan model Miles dan Huberman melalui display data, reduksi data, dan verifikasi data. Hasil penelitian menunjukkan bahwa reaksi peserta diklat terhadap pembelajaran oleh widyaiswara berada pada kategori memadai dengan skor 76,67 \%, reaksi peserta diklat terhadap pembelajaran ceramah oleh narasumber berada pada kategori memadai dengan skor 75,17\%, kemampuan coach menurut peserta dengan skor 82,93\%, sistem pengelolaan baik dari segi administrasi dan operasional sebesar 70,62\%. Reaksi peserta terhadap aspek tenaga kediklatan yaitu sebesar 79,03\%. Efektivitas program dari segi reaksi peserta adalah pada skor 65,52 atau pada kategori memadai dan hasil kuesioner $91,67 \%$ peserta menganggap pengetahuan yang diberikan selama diklat kurang bersifat praktis.
\end{abstract}

Kata kunci: Evaluasi program, model kirkpatrik, kepemimpinan, pendidikan dan pelatihan

\section{PENDAHULUAN}

Sumber daya aparatur mempunyai peran penting dalam mengembangkan tatanan pemerintahan. Pergeseran paradigma penyelenggaraan pemerintahan dari "rule government" menjadi "good governance" dan dari sentralistik ke desentralistik, perlu disikapi dan diimbangi dengan sumber daya aparatur yang memiliki kompetensi yang memadai dan sesuai tuntutan nasional dan tantangan global.

* Ismail, IAIN Mataram, Jl. Lestrai Gg. Manalagi XI No.6 Pejeruk, Ampenan Lombok, NTB. Telepon:08123706275/087865555560,email: ismail_thoib@yahoo.com 
Persoalan kompetensi aparatur memang merupakan determinan penting mengingat dipundak aparatur memiliki tugas ganda, selain dituntut harus mampu memberikan layanan pada masyarakat secara adil dan transfaran, dan juga harus mampu menunjukkan loyalitas, dedikasi dan etoos kerja serta integritas yang tinggi. Tugas ganda tersebut akan dapat terealisasi manakala didukung dengan kompetensi aparatur yang profesional.

Kompetensi bagi aparatur negara menjadi salah satu pertimbangan dalam pengangkatan jabatan dan pengembangan karier. Selain itu, kompetensi menjadi tuntutan dan kewajiban untuk dimilikinya dengan alasan tugas pokok, fungsi, kewenangan dan tanggungjawab yang harus dilaksanakan dalam pelayanan publik, kepemerintahan yang baik, mengimbangi perubahan lingkungan strategis internal dan eksternal, perkembangan ilmu pengetahuan dan teknologi, serta tuntutan pelaksanaan otonomi daerah. Undang-Undang Nomor 5 Tahun 2014 tentang Aparatur Sipil Negara, Pasal 70 ayat 1 mengamanatkan bahwa setiap Pegawai ASN memiliki hak dan kesempatan untuk mengembangkan kompetensi.

Salah satu upaya peningkatan kompetensi aparatur adalah melalui Pendidikan dan Pelatihan (Diklat). Diklat memiliki peran strategis dalam meningkatkan kualitas sumber daya aparatur professional dengan kompetensi, sikap dan perilaku sesuai harapan dan fungsinya dalam jabatan tertentu. Namun demikian, beberapa hasil penelitian dan fakta di lapangan menunjukkan bahwa penyelenggaraan diklat selama ini belum memberikan output dan outcome yang jelas bagi alumni dan organisasinya. Hal ini memperlihatkan bahwa tingkat ketercapaian tujuan kebijakan (the degree of accomplishment) belum optimal. Keikutsertaan seorang pegawai dalam diklat bukan saja tidak memberikan kemanfaatan terhadap karir pegawai, namun juga tidak memberikan kemanfaatan bagi organisasi. Hal tersebut lebih banyak disebabkan oleh belum adanya keterkaitan antara kebijakan kepegawaian dengan kebijakan diklat. Kurikulum, program, dan materi diklat lebih menonjolkan ranah kognitif dan psikomotorik daripada ranah afektif. Kompetensi lulusan belum sebanding dengan investasi yang dikeluarkan dan dinamika tuntutan penyelenggaraan pemerintahan dan pembangunan.

Diklat seharusnya dapat menjadi solusi kesenjangan kompetensi aparatur. Keikutsertaan peserta, cakupan materi dan model delivery-nya serta teknis pelaksanaannya didesain sebagai pencerminan kultur adult education yang sekaligus memadukan pembentukan disiplin, kapasitas akademis dan administratif dalam suasana kolegial. Sistem rekruitmen peserta didasarkan pada kebutuhan organisasi, alasan peningkatan kinerja, kemampuan dan keterampilan pegawai, kepangkatan dan sebagainya (Thoha, 2005:70).

Salah satu bentuk reformasi kediklatan yang tengah dilakukan oleh lembaga pembina diklat aparatur yaitu Lembaga Administrasi Negara (LAN) adalah dengan adanya perubahan pola penyelenggaraan diklat aparatur. Penyelenggaraan diklat pola baru untuk Diklat Prajabatan dan Diklat Kepemimpinan melalui perubahan kurikulum dan pola pembelajaran yang in class dan off campus serta penekanan pada pembentukan karakter. Hal ini terbukti dengan dikeluarkannya Peraturan Kepala LAN (Perkalan) Nomor 10, 11, 12, dan 13 Tahun 2013 tentang Pedoman Penyelenggaraan Diklat Kepemimpinan ingkat I, II, III, dan IV serta Perkalan Nomor 38 dan 39 Tahun 2014 tentang Pedoman Penyelenggaraan Diklat Prajabatan CPNS Golongan I-II dan III.

Sejak tahun 2014, penyelenggaraan Diklat Kepemimpinan mengalami perubahan pola penyelenggaraan untuk lebih meningkatkan kualitas, efisiensi, dan efektivitas diklat. Perubahan pola tersebut dilaksanakan dengan alasan bahwa kurikulum diklat pola sebelumnya dirasakan masih lemah dilihat dari sisi jumlah dan substansi mata diklat kurang menyentuh aspek kepemimpinan terutama pada sisi praktik. Selain itu, metode pembelajaran klasikal diubah dengan berbasis pengalaman (experiential learning) dan praktik kepemimpinan serta penekanan lebih besar pada aspek pembentukan karakter dan integritas peserta.

Penyelenggaraan Diklat Kepemimpinan Tingkat IV di Provinisi NTB selama ini mengacu kepada Peraturan Kepala LAN RI Nomor 541/ XIII/10/6/2001 tentang Pedoman Penyelenggaraan Diklat Kepemimpinan Tingkat IV tanggal 10 Agustus 2001. Selanjutnya, berdasarkan Peraturan Kepala LAN RI Nomor 13 Tahun 2013 tentang Pedoman Penyelenggaraan Diklat Kepemimpinan Tingkat IV tanggal 24 September 2013, maka penyelenggaraan Diklat Kepemimpinan Tingkat IV harus mengikuti 
kurikulum pola baru kepemimpinan perubahan yang mulai diterapkan sejak tanggal 2 Januari 2014.

Kebermaknaan program Diklat Kepemimpinan Tingkat IV akan efektif jika kegiatan tersebut diakhiri dengan evaluasi. Evaluasi dalam aktivitas diklat dapat berupa evaluasi hasil belajar dan evaluasi program. Evaluasi hasil belajar lebih difokuskan untuk menilai hasil belajar yang dicapai oleh peserta setelah mengikuti program diklat. Sedangkan evaluasi program dilakukan untuk menilai efektivitas dan efisiensi program. Evaluasi program bersifat lebih holistik daripada evaluasi hasil belajar.

Semua aspek dan komponen sistem diklat dapat dinilai efektivitas dan efisiensinya melalui evaluasi program. Evaluasi diklat dilaksanakan dengan tiga alasan khusus, yaitu: (1) untuk menentukan efektivitas suatu program diklat dan mendapatkan informasi untuk mengembangkan program diklat pada masa yang akan datang; (2) untuk menentukan apakah program diklat diteruskan, dimodifikasi, atau dihentikan; (3) untuk memberikan bukti nyata mengenai keberadaan lembaga pelatihan dengan menunjukkan kontribusinya terhadap sasaran serta tujuan perusahaan (Kirkpatrick, 2005: 17).

Diklat mencakup tiga aspek pokok yaitu perolehan pengetahuan, keterampilan, dan sikap perilaku dalam upaya meningkatkan kinerja pegawai dalam melaksanakan tugas dan tanggung jawabnya. Struktur kurikulum Diklat Kepemimpinan Tingkat IV disusun menjadi lima tahap pembelajaran: (1) Tahap Diagnosa Kebutuhan Perubahan, tahap penentuan area pengelolaan kegiatan organisasi yang akan mengalami perubahan; (2) Tahap Taking Ownership (Breakthrough I), pembelajaran yang mengarahkan peserta membangun organizational learning atau kesadaran dan pembelajaran bersama akan pentingnya mereformasi area kegiatan organisasi yang bermasalah. Mata diklat pada tahap ini adalah couching and counseling; (3) Tahap Merancang Perubahan dan Membangun Tim, membekali peserta dengan pengetahuan membuat rancangan perubahan yang komprehensif menuju kondisi ideal pengelolaan organisasi yang dicita-citakan; (4) Tahap Laboratorium Kepemimpinan (Breakthrough II), tahap ini mengarahkan peserta untuk menerapkan dan menguji kapasitas kepemimpinannya di tempat kerjanya dan memimpin implementasi perubahan yang telah dibuatnya. Mata diklat pada tahap ini adalah couching and counseling; (5) Tahap
Evaluasi, merupakan tahap berbagi pengetahuan dan pengalaman dalam memimpin implementasi proyek perubahan. Kegiatan tersebut dilakukan dalam bentuk seminar. Mata diklat pada tahap ini adalah Seminar Laboratorium Kepemimpinan dan Evaluasi.

Secara khusus evaluasi program pada lembaga pemerintah dan pendidikan merupakan proses untuk menjamin akuntabilitas dan peningkatan berkelanjutan (Edward, Scott dan Nambury, 2007: 3). Kualitas penyelenggaraan diklat kepemimpinan harus dilihat secara menyeluruh terhadap keseluruhan tahapan mulai dari persiapan, pelaksanaan, sampai kepada hasil penilaian serta dampak diklat terhadap peningkatan produktivitas atau kinerja layanan organisasi.

Evaluasi model Kirkpatrik sangat relevan dengan komponen yang melekat dalam pelaksanaan diklat. Penerapan model Kickpatrick dalam penelitian ini meliputi level reaksi (reaction), pembelajaran (learning), perilaku (behaviour), dan hasil (result). Secara umum penelitian ini bertujuan untuk mengetahui keberhasilan penyelenggaraan program Diklat Kepemimpinan Tingkat IV Pemerintah Provinsi NTB. Secara operasional penelitian evaluasi ini memiliki tujuan: (1) Mengetahui kepuasan peserta terhadap pelaksanaan program Diklat Kepemimpinan Tingkat IV Pemerintah Provinsi NTB (reaction); (2) Mengukur pencapaian pengetahuan, sikap, dan keterampilan peserta setelah mengikuti Diklat Kepemimpinan Tingkat IV Pemerintah Provinsi NTB (learning); (3) Mengetahui penerapan perubahan perilaku peserta Diklat Kepemimpinan Tingkat IV Pemerintah Provinsi NTB (behaviour); dan (4) Mengetahui dampak perubahan perilaku peserta Diklat Kepemimpinan Tingkat IV Pemerintah Provinsi NTB (result).

Evaluasi reaksi merupakan tahap evaluasi yang melihat efektivitas program diklat berdasarkan reaksi atau tanggapan peserta terhadap pelaksanaan program yang diikuti. Evaluasi reaksi ini disebut juga lembar kepuasan pelanggan (customer satisfaction sheet) karena bertujuan mendapatkan masukan dan komentar peserta terhadap program diklat berdasarkan kepuasan peserta terhadap pelayanan dari penyelenggara program menyangkut kurikulum, tenaga kediklatan, dan fasilitas yang mereka terima. Aspek kurikulum meliputi pengaturan jadwal, pengembangan materi, penggunaan metode, pemilihan media, kegiatan benchmarking, dan 
pelaksanaan praktik kepemimpinan. Aspek tenaga kediklatan mencakup widyaiswara, narasumber, penyelenggara, coach, dan mentor. Aspek fasilitas diklatmeliputi ruang kelas, asrama, sarana pendukung, dan konsumsi. Evaluasi Tingkat kepuasan peserta sangat bergantung kepada kualitas produk atau jasa yang didapatkannya. Montgomery dalam Supranto (2011: 2) membedakan mutu atau kualitas menjadi dua, yaitu mutu desain dan mutu kecocokan (quality of design and quality of conformance).

Evaluasi pembelajaran dalam diklat mencakup: knowledge, skills, and attitudes (Blanchard dan James, W.T. (2007: 348). Mc Alpine dalam Gagne (2005: 265) menjelaskan bahwa pembelajaran merupakan refleksi dari authentic assessement dalam berbagai cara, meliputi: (1) produk seperti buku, permainan, peta, dan pameran; (2) proses kognitif seperti berpikir level tinggi meliputi analisis, sintesis, evaluasi, dan kreativitas sebaik perolehan, pengorganisasian, dan penggunaan informasi; (3) kinerja seperti pelaksanaan eksperimen dan penelitian, presentasi temuan, pertunjukan permainan; dan (4) sikap dan keterampilan sosial seperti sains berbeda budaya dan wawancara individu dan kelompok. Sudjana (2009: 22) menjelaskan bahwa hasil belajar sebagai kemampuan-kemampuan yang dimiliki peserta diklat setelah menerima pengalaman belajarnya.

Evaluasi perilaku difokuskan pada perilaku kerja (pengetahuan, keterampilan, serta sikap dan perilaku) peserta diklat setelah kembali ke dalam lingkungan kerjanya. Perilaku yang dimaksud berupa perilaku kerja yang ada hubungannya langsung dengan materi diklat, dan bukan perilaku dalam konteks hubungan personal dengan rekanrekan kerjanya. Perubahan yang ingin diketahui dalam evaluasi ini adalah seberapa jauh perubahan sikap mental (attitude), perbaikan pengetahuan, dan atau penambahan ketrampilan peserta membawa pengaruh langsung terhadap kinerja peserta ketika kembali ke lingkungan kerjanya. Apakah perubahan tersebut diimplementasikan dalam lingkungan kerja peserta ataukah dibiarkan berkarat dalam diri peserta tanpa pernah diimplementasikan.

Evaluasi hasil difokuskan pada hasil akhir (final result) yang terjadi karena peserta telah mengikuti suatu program (Widoyoko, 2012: 178). Evaluasi level result atau hasil dilakukan untuk mengukur kontribusi program secara keseluruhan terhadap kinerja perusahaan (Pribadi, 2014: 165). Evaluasi level hasil merupakan produk akhir berupa dampak diklat terhadap tingkat produktivitas organisasi yang dapat ditingkatkan setelah alumni dapat menerapkan pengetahuan dan keterampilan yang didapat selama diklat. Perubahan perilaku kerja diharapkan memberikan dampak positif terhadap tempat kerja terutama berhubungan dengan pelayanan publik.

\section{METODE PENELITIAN}

Penelitian ini menggunakan metode penelitian evaluasi dengan pendekatan kualitatif. Evaluasi kualitatif digunakan untuk mengevaluasi karakter, petunjuk, dan efisiensi staf berdasarkan latar belakang dan pengetahuan kegiatan yang relevan (Jacobs \& Christine, 2010: 424). Proses evaluasi kebanyakan memerlukan deskripsi rinci tentang berjalannya suatu program. Deskripsi berdasarkan pada observasi dan atau wawancara dengan staf, peserta diklat, dan petugas administrasi program. Proses evaluasi menggambarkan secara tepat dan rinci jalannya program menggunakan metode kualitatif (Patton, 2009: 31). Dilakukan terhadap penyelenggaraan Diklat Kepemimpinan Tingkat IV Pemerintah Provinsi NTB yang dilaksanakan pada BKD dan Diklat Provinsi NTB. Peserta Diklat Kepemimpinan Tingkat IV sebanyak 60 orang yang terbagi dalam dua angkatan. Penelitian dilaksanakan dari bulan Juli 2014 sampai dengan Desember 2014. Metode kualitatif dalam evaluasi ini bersifat deskriptif.

Evaluasi kualitatif deskriptif lebih diarahkan untuk menentukan efektivitas program Diklat Kepemimpinan Tingkat IV Pemerintah Provinsi NTB. Efektivitas program diklat mencerminkan kualitas layanan penyelenggaraan program dengan melihat kepuasan terhadap layanan yang diberikan kepada peserta diklat serta perubahan perilaku dan hasil program bagi peningkatan kinerja organisasi. Evaluasi dilakukan terhadap empat level evaluasi model Kirkpatrick yang terdiri atas reaksi (reaction), pembelajaran (learning), perilaku (behaviour), dan hasil (result).

Pengumpulan data dilakukan melalui wawancara, observasi, studi dokumentasi dan kuesioner. Observasi dilakukan secara langsung ke lokasi penelitian pada saat penyelenggaraan program. Wawancara dilakukan dengan berinteraksi dan berkomunikasi langsung dengan peserta diklat, atasan dan bawahan peserta diklat pada unit kerjanya, penyelenggara diklat, widyaiswara, narasumber 
dan coach. Studi dokumentasi ini dimaksudkan untuk melihat dan menganalisis data tertulis yang digunakan dalam penyelenggaraan diklat. Dokumen yang diteliti berupa berbagai macam baik dokumen primer maupun dokumen sekunder. Kuesioner diberikan kepada peserta diklat untuk mengukur tingkat kepuasan terhadap proses pelaksanaan diklat yang diikuti menyangkut aspek kurikulum, tenaga kediklatan, dan fasilitas diklat.

Analisis data dilakukan dengan menggunakan tiga alur kegiatan secara bersamaan dari methode Miles dan Huberman (2009: 20), yaitu reduksi data, penyajian data, penyimpulan dan verifikasi data. Prosedur Analisis data melalui reduksi, display, dan verifikasi data dalam bentuk naratif. Proses pengolahan data hasil penelitian, mulai darimenyusun, mengelompokkan, menelaah dan menafsirkan data dalam pola, serta menghubungkannya dengan fokus evaluasi. Data mentah hasil observasi dan wawancara ditabulasi dalam bentuk tally kemudian dihitung persentase yang dijadikan dasar dalam pemberian keputusan.

Setelah melalui proses pengumpulan dan analisis data, peneliti harus memastikan bahwa hasil temuan dan interpretasi sudah akurat. Validasi temuan dilakukan melalui berbagai strategi member checking dan triangulasi. Cara ini dimaksudkan untuk mengurangi bias yang melekat pada suatu metode dan memudahkan melihat keluasan penjelasan yang dikemukakan. Dalam proses penelitian, peneliti menanyakan kepada satu atau beberapa sumber data atau partisipan yang terlihat untuk mengecek keakuratan data yang telah dianalisis. Cara ini untuk memberikan keobjektifan dan kebenaran data sehingga informasi yang diperoleh dan disimpulkan dapat dipertanggungjawabkan. Member checking dilakukan secara tertulis melalui terhadap kuesioner, wawancara atau teknik dokumentasi.

\section{HASIL PENELITIAN DAN PEMBAHASAN}

Diklat Kepemimpinan Tingkat IV Pemerintah Provinsi NTB Tahun 2014 dilaksanakan dalam dua angkatan, yaitu angkatan II dan III. Peserta diklat merupakan PNS yang sedang menduduki Jabatan Eselon IV lingkup Pemerintah Provinsi NTB. Peserta diklat angkatan II sebanyak 30 orang terdiri atas 20 orang laki-laki atau sebesar $66,67 \%$ dan 10 orang perempuan atau sebesar 33,33\%. Angkatan III diikuti oleh 30 orang peserta terdiri atas 19 orang laki-laki atau sebesar $63,33 \%$ dan 11 orang perempuan atau sebesar $36,67 \%$. Pangkat dan jabatan peserta diklat bervariasi mulai dari golongan III/b sampai kepada golongan IV/a. Peserta dengan pangkat dan golongan Penata Muda Tingkat I (III/b) sebanyak 1 orang atau sebesar $1,67 \%$; Penata (III/c) sebanyak 21 orang atau sebesar 35\%; Penata Tingkat I (III/d) sebanyak 34 orang atau sebesar 56,67\%; dan Pembina (IV/a) sebanyak 4 orang atau sebesar 6,66\%. Pengalaman kerja Peserta Diklat Kepemimpinan Tingkat IV bervariasi mulai dari 10 tahun atau kurang sampai 26 tahun. Masa kerja 10 tahun atau kurang sebanyak 3 orang atau sebesar 5\%; masa kerja antara $11-14$ tahun sebanyak 20 orang atau sebesar $33,33 \%$; masa kerja antara 15 - 18 tahun sebanyak 14 orang atau sebesar $23,33 \%$; masa kerja antara 19 - 22 tahun sebanyak 16 orang atau sebesar $26,67 \%$; dan masa kerja antara $23-26$ tahun sebanyak 7 orang atau sebesar 11,67\%. Tingkat pendidikan peserta dikelompokkan sebagai berikut: (1) tingkat pendidikan SMA sebanyak 3 orang atau sebesar 5\%; (2) Diploma III sebanyak 2 orang atau sebesar 3,33\%; (3) S1/DIV sebanyak 46 orang atau sebesar 76,67\%; dan (4) tingkat pendidikan S2 sebanyak 9 orang atau sebesar $15 \%$.

Diklat Kepemimpinan Tingkat IV Pemerintah Provinsi NTB diselenggarakan oleh BKD dan Diklat Provinsi NTB. Lembaga tersebut merupakan salah satu lembaga diklat terakreditasi yang diberikan kewenangan untuk menyelenggarakan diklat prajabatan, diklat kepemimpinan, diklat teknis, dan diklat fungsional umum pada lingkup Pemerintah Provinsi NTB.

\section{Evaluasi Reaksi}

Diklat Kepemimpinan Tingkat IV Provinsi NTB dilaksanakan selama 97 hari kerja yang terbagi dalam 282 Jam Pelajaran (JP) atau 32 hari kerja untuk pembelajaran klasikal, dan $585 \mathrm{JP}$ atau 65 hari kerja untuk pembelajaran non klasikal yang diistilahkan dengan breakthrough. Pembelajaran breakthrough tersebut dilaksanakan sebanyak dua tahapan, yaitu tahap taking ownership selama 5 hari dan tahap laboratorium kepemimpinan selama 60 hari. Selama pembelajaran klasikal peserta diasramakan dan diberikan kegiatan penunjang kesehatan jasmani/mental sebanyak 14 JP. Jadwal pelaksanaan Diklat Kepemimpinan Tingkat IV Angkatan II dan III Pemerintah Provinsi NTB sesuai tahapan pembelajaran diklat kepemimpinan seperti 
terlihat pada tabel di bawah ini.

Tabel 1. Jadwal Tahapan Pelaksanaan Diklat Kepemimpinan Tingkat IV

\begin{tabular}{|c|c|c|}
\hline $\begin{array}{c}\text { Tahapan } \\
\text { Pembelajaran }\end{array}$ & Angkatan II & $\begin{array}{l}\text { Angkatan } \\
\text { III }\end{array}$ \\
\hline $\begin{array}{ll}\text { I. Tahap Diagnosa } \\
\text { Kebutuhan } \\
\text { Perubahan }\end{array}$ & $\begin{array}{l}11 \text { s.d. } 22 \\
\text { Agustus } 2014\end{array}$ & $\begin{array}{l}12 \text { s.d. } 23 \\
\text { Agustus } \\
2014\end{array}$ \\
\hline $\begin{array}{l}\text { II. Tahap Taking } \\
\text { Ownership } \\
\text { (Breakthrough I) }\end{array}$ & $\begin{array}{l}23 \text { s.d. } 28 \\
\text { Agustus } 2014\end{array}$ & $\begin{array}{l}24 \text { s.d. } 29 \\
\text { Agustus } \\
2014\end{array}$ \\
\hline $\begin{array}{l}\text { III. Tahap Merancang } \\
\text { Perubahan dan } \\
\text { Membangun Tim } \\
\text { Efektif }\end{array}$ & $\begin{array}{l}29 \text { Agustus } \\
\text { s.d. } \\
\text { 19 September } \\
2014\end{array}$ & $\begin{array}{l}30 \text { Agustus } \\
\text { s.d. } \\
20 \\
\text { September } \\
2014\end{array}$ \\
\hline 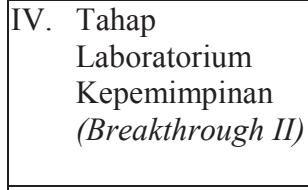 & $\begin{array}{l}20 \text { September } \\
\text { s.d. } 18 \\
\text { November } \\
2014\end{array}$ & $\begin{array}{l}22 \\
\text { September } \\
\text { s.d. } 20 \\
\text { November } \\
2014 \\
\end{array}$ \\
\hline V. Tahap Evaluasi & $\begin{array}{l}19 \text { dan } 20 \\
\text { November } \\
2014\end{array}$ & $\begin{array}{l}21 \text { dan } 22 \\
\text { November } \\
2014\end{array}$ \\
\hline
\end{tabular}

Materi diklat pada Diklat Kepemimpinan Tingkat IV Pemerintah Provinsi NTB diserahkan pengembangannya kepada tenaga pengajar khususnya widyaiswara. Lembaga Administrasi Negara tidak menyiapkan bahan diklat. Pengembangan materi diklat harus sesuai dengan tujuan diklat. Pengembangan materi mengarah kepada pencapaian tujuan diklat, tujuan kurikuler, dan tujuan institusional. Tujuan institusional mengarah kepada harapan dan kebutuhan lembaga terhadap kompetensi yang ingin dicapai. Sitepu (2012: 20) menjelaskan bahwa kehadiran buku baik dalam bentuk cetakan maupun dalam bentuk elektronik telah memberikan pengaruh besar dalam proses belajar dan membelajarkan. Hal tersebut juga disampaikan oleh Atwi Suparman (2012: 283) bahwa kegiatan instruksional ada tiga macam sehingga melahirkan tiga bentuk bahan instruksional. Pertama, mengajar sebagai fasilitator dan peserta didik belajar mandiri dengan menggunkan bahan instruksional mandiri yang didesain secara khusus. Kedua, pengajar sebagai penyaji bahan instruksional yang dipilihnya dengan menggunakan bahan instruksional kompilasi. Ketiga, pengajar sebagai fasilitator dan atau penyaji bahan instruksional dengan menggunakan kombinasi dua bentuk bahan instruksional yaitu bahan instruksional mandiri dan bahan kompilasi. Setiap bentuk kegiatan instruksional di atas membutuhkan bahan instruksional yang berbeda. Untuk kepentingan jurnal dg jumlah halaman yang terbatas (lebih kurang maksimal 10 halaman) perlu diringkas untuk bagian pembahasan, bagian di atas tidak perlu masuk pembahasan. Sebaiknya langsung ke pembahasan inti saja tidak perlu panjang lebar.

Kedalaman dan keluasan materi pembelajaran yang diberikan widyaiswara sangat bergantung kepada pemahaman dan pengalamannya yang berhubungan dengan mata diklat yang diajarkan. Hal ini berarti bahwa cakupan materi sangat bergantung kepada siapa yang memberikan materi tersebut. Widyaiswaralah yang memiliki peran dalam memperkaya materi diklat dengan teori-teori terbatu atau pengkayaan materi dengan pengalaman kerja atau dengan memberikan ilustrasi dari contoh real di birokrasi pemerintahan. Haris Mujiman (2011: 5960) menjelaskan bahwa program pelatihan PNS di Indonesia lebih bersifat spesifik. Kebutuhan diklat ditetapkansetelahdilakukananalisisterhadapdeskripsi tugas tiap jenjang jabatan. Hasil analisis mengarah pada identifikasi kebutuhan pengetahuan, sikap, dan keterampilan yang diperlukan untuk menjalankan pekerjaan pada jenjang tersebut. Kebutuhan itulah yang dijadikan acuan penentuan bahan diklat. Semua peserta diasumsikan membutuhkan materi-materi tersebut walaupun karakteristik peserta berasal dari latar belakang pengalaman kerja serta kemampuan yang berbeda. Asumsi lainnya adalah peserta diklat memiliki kemampuan yang sama dalam menyerap materi pelajaran.

Metode pembelajaran yang digunakan selama pembelajaran di dalam kelas oleh widyaiswara dikatakan oleh peserta diklat sudah cukup bagus. Widyaiswara memiliki keterampilan dalam mengelola kelas dalam pembelajaran. Metode pembelajaran yang sering digunakan oleh widyaiswara adalah metode diskusi, Tanya jawab, ceramah, pemutaran film pendek, dan disertai game-game ringan untuk mempertahankan konsentrasi peserta. Metode pembelajaran yang disarankan dalam pembelajaran diklat adalah berbasis pengalaman (experiential learning). Auerbach (2013: 143) pendekatan pembelajaran eksperiensial (pembelajaran bersumber pengalaman) sangat cocok untuk pelatihan efektif dan behavioral. Metode tersebut membantu para peserta menyadari perasaan dan reaksi mereka 
terhadap isu dan ide baru serta memungkinkan peserta untuk berlatih dan mengasah keterampilan dan prosedur baru. Pendekatan utama dalam pembelajaran eksperensial adalah permainan peran, game dan simulasi, observasi, pencitraan mental, tugas menulis, dan proyek pembelajaran tindakan. Reaksi peserta terhadap metode pembelajaran

Media yang sudah disiapkan oleh penyelenggara pada pembelajaran adalah berupa $L C D$, papan tulis, dan flip chart. Tenaga pengajar lebih banyak hanya membuat bahan tayang (slide) yang dapat dilengkapi dengan gambar-gambar, musik, atau film yang digunakan dan ditampilkan melalui laptop dalam pembelajaran. Pemanfaatan media dalam penelitian ini meliputi aspek pemilihan dan pemanfaatan media pembelajaran.

Benchmarking dilaksanakan selama lima hari, yaitu angkatan II dilaksanakan tanggal 9 sampai 12 September 2014, dan angkatan III pada tanggal 8 sampai 13 September 2014. Daerah yang dijadikan lokus benchmarking Angkatan II adalah Provinsi Kalimantan Selatan, sedangkan Angkatan II ke Kota Makasar Provinsi Sulawesi Selatan. Instansi yang dikunjungi di Provinsi Kalimatan Selatan adalah Bappeda dan Badan Perijinan Terpadu yang dinilai bagus sehingga perlu dijadikan pembanding. Angkatan III menjadikan Badan Layanan Umum Terpadu dan Dinas Perhubungan dan Kominfo Kota Makasar yang dijadikan tujuan kunjungan. reaksi atau penilaian kepuasan peserta diklat terhadap kegiatan benchmarking ke best practice berada pada kategori memadai dengan skor $69,20 \%$.

Laboratorium kepemimpinan dilaksanakan selama 60 hari kerja (12 minggu). Kegiatan yang dilaksanakan peserta diklat adalah mengimplementasikan rancangan proyek perubahan yang sudah diseminarkan pada seminar rancangan proyek perubahan. Implementasi rancangan proyek perubahan ditekankan pada pelaksanaan tiap tahapan pada roadmap proyek perubahan, kegiatan memobilisasi dukungan stakeholders dan capaian proyek perubahan sesuai tujuan yang sudah direncanakan. Laboratorium kepemimpinan diarahkan kepada bagaimana peserta memimpin perubahan pada unit kerjanya sesuai rancangan yang dibuat sebelumnya. Menciptakan perubahan menurut Flamholtz dan Yvonne R. (2008:49) bahwa pemimpin perubahan adalah orang yang memiliki visi yang besar dan seperangkat karismatik yang menentukan efektivitas kepemimpinan.

Secara umum, penilaian peserta terhadap aspek kurikulum pada komponen jadwal, materi, metode, media, benchmarking, dan laboratorium kepemimpinan dapat dilihat pada gambar di bawah ini.

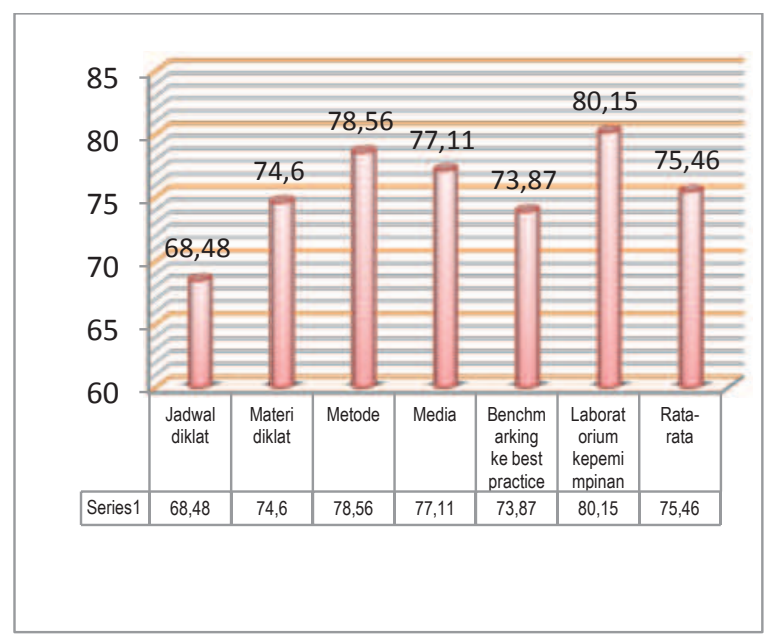

Gambar 1. Reaksi Peserta terhadap Aspek Kurikulum

Widyaiswara yang dilibatkan dalam penyelenggaraan Diklat kepemimpinan Tingkat IV Provinsi NTB sebanyak 10 orang. Widyaiswara tersebut terdiri atas 9 orang laki-laki dan 1 orang perempuan serta 2 orang termasuk dalam jabatan widyaiswara utama dan 8 orang lainnya masih dalam jabatan widyaiswara madya. reaksi peserta diklat terhadap pembelajaran oleh widyaiswara berada pada kategori memadai dengan skor 76,67. Penilaian reaksi peserta diberikan terhadap 11 aspek kinerja widyaiswara, yaitu latar belakang pendidikan, penguasaan materi, sistematika penyajian, pengaitan materi dengan proyek perubahan, pemberian ilustrasi, penggunaan bahasa, komunikasi interaktif, pelibatan peserta, merespon peserta, pembelajaran andragogi, dan pemberian motivasi. Rasio jumlah Widyaiswara selaku tenaga pengajar dengan kebutuhan diklat menunjukkan bahwa jumlah widyaiswara pada BKD dan Diklat Provinsi NTB sebanyak 10 orang. Jika melihat jumlah tenaga widyaiswara dengan kebutuhan diklat (diklat umum, diklat teknis, dan diklat fungsional) yang dilaksanakan dalam satu tahun, maka jumlah widyaiswara dan kebutuhan diklat belum ada kesesuaian.

Narasumber yang digunakan pada Diklat 
Kepemimpinan Tingkat IV berasal dari akademisi Perguruan Tinggi Negeri di Mataram dan praktisi dari perusahaan. reaksi peserta diklat terhadap pembelajaran ceramah oleh narasumber berada pada kategori memadai dengan skor 75,17. Penilaian reaksi peserta diberikan terhadap 6 aspek kinerja narasumber meliputi: keahlian, penguasaan materi, sistematika penyajian, penggunaan bahasa, dan gaya komunikasi.

Jumlah coach pada Diklat Kepemimpinan Tingkat IV Provinsi NTB Tahun 2014 sebanyak 5 orang yang terbagi dalam 2 angkatan. Setiap angkatan dibimbing oleh 3 orang coach yang masing-masing membimbing 10 orang peserta. kemampuan coach menurut peserta berada pada kategori sangat memadai atau dengan skor $82,93 \%$. Indikator penilaiannya meliputi pemahaman perannya, cara membimbing, pemberian saran, motivasi, dan komunikasi yang dibangun dengan peserta.

Mentor adalah atasan langsung peserta Diklat. Atasan langsung berupa pejabat eselon III dan secara struktural langsung berada di atas peserta pada instansinya yaitu sedang menduduki jabatan Kepala Bidang, Kepala Bagian, Sekretaris, atau Kepala UPT. Jumlah mentor pada Diklat Kepemimpinan Tingkat IV Provinsi NTB Tahun 2014 sebanyak 58 orang. Jumlah tersebut lebih sedikit dari jumlah. reaksi peserta terhadap kemampuan mentor dalam pelaksanaan perannya berada pada kategori sangat memadai.

Penyelenggara diklat memiliki kemampuan dalam mengelola dan menyelenggarakan diklat. tenaga penyelenggara yang sudah mengikuti $T o F$ diklat kepemimpinan pola baru hanya Kabid Diklat Penjenjangan sendiri dan 2 orang Kasubidnya. Sementara staf belum pernah mengikuti ToF . Kondisi tersebut memberikan kesulitan terutama dalam sistem pengelolaan tahapan kegiatan diklat baik dari sisi administrasi maupun operasionalnya. reaksi peserta sebesar 70,62\%. Keberhasilan institusi Diklat dalam mengemban misinya sangat ditentukan oleh mutu keinterelasian unsur-unsur sistemik yang memberikan kontribusi terhadap peningkatan kualitas transformasi dan mutu hasil kerjanya (Danim, 2008: 275).

Secara umum, reaksi peserta terhadap aspek tenaga kediklatan yang mencakup kemampuan widyaiswara, narasumber, coach, mentor, dan kapasitas penyelenggara berada pada kategori memadai yaitu dengan skor rata-rata sebesar 79,03\%. Selengkapnya, reaksi peserta terhadap kemampuan tenaga kediklatan seperti dilihat pada gambar di bawah ini.

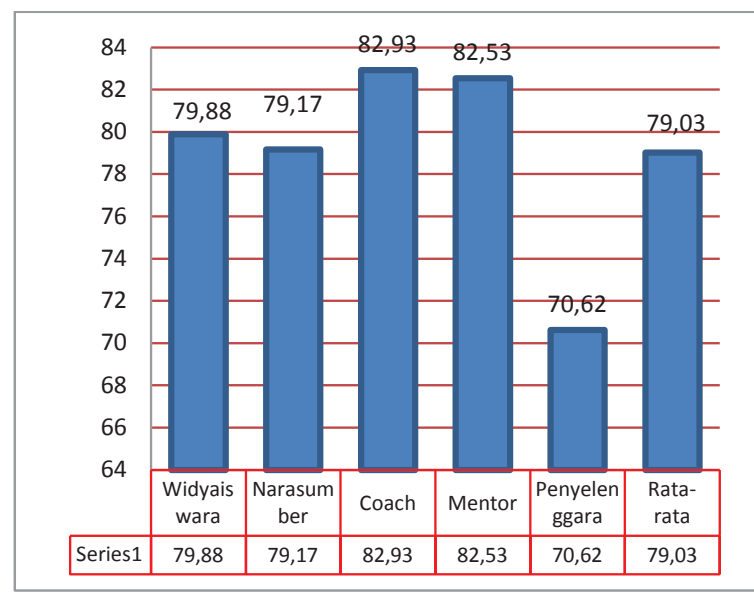

Gambar 2. Reaksi Peserta terhadap Aspek Tenaga Kediklatan

Fasilitas diklat merupakan alat bantu dan penunjang yang digunakan untuk menjamin efektivitas agenda pembelajaran. Fasilitas diklat meliputi sarana dan prasarana kediklatan sesuai standar persyaratan setiap jenis, jenjang, dan program diklat serta jumlah peserta. Komponen fasilitas (sarana dan prasarana) diklat dianalisis berdasarkan ketersediaan serta kelayakan sarana dan prasarana dalam mendukung proses Diklat Kepemimpinan Tingkat IV di BKD dan Diklat Provinsi NTB. Ketersediaan sarana dan prasarana merupakan bagian yang tidak dapat dipisahkan dari proses Diklat terutama untuk menunjang tercapainya tujuan yang diinginkan.

Ruang kelas merupakan tempat belajar yang memungkinkan peserta diklat bergerak leluasa dan tidak berdesak-desakan serta saling mengganggu saat melakukan pembelajaran. Besarnya ruang kelas tergantung pada jenis dan jumlah peserta yang mengikuti diklat. Different kinds of learnings require different environments (Laird, 2003: 195). Jenis pembelajaran yang lebih mengarah kepada skill memerlukan lingkungan belajar yang mendukung percepatan pencapaian skill yang diinginkan. 


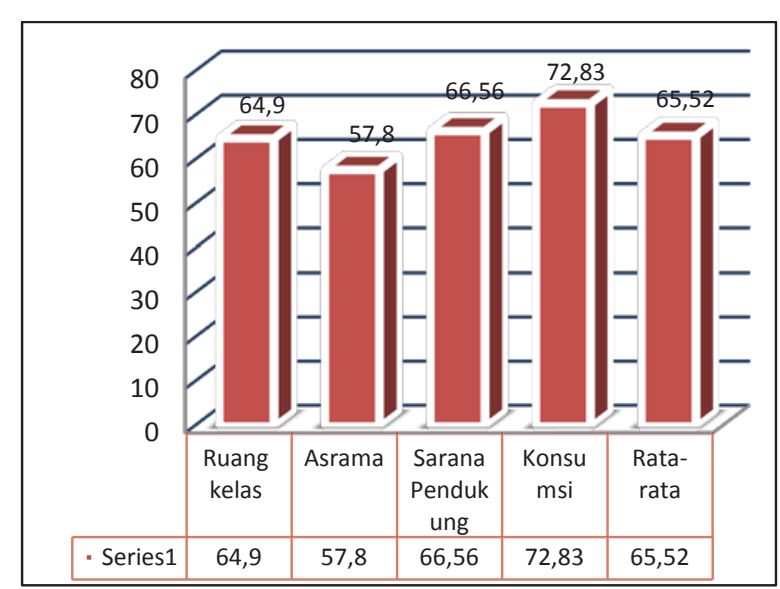

Gambar 3. Reaksi Peserta terhadap Aspek Fasilitas

Hasil analisis kuesioner pada aspek fasilitas diklat terhadap empat komponen yaitu ruang kelas, asrama, sarana pendukung, dan konsumsi menunjukkan bahwa tingkat keberhasilan atau efektivitas program dari segi reaksi peserta adalah berada pada skor 65,52 atau pada kategori memadai. Hasil selengkapnya seperti terlihat pada gambar di bawah ini,

\section{Evaluasi Pembelajaran}

Evaluasi pembelajaran dimaksudkan untuk mengukur peningkatan pengetahuan, sikap, dan keterampilan yang diperoleh sebagai hasil diklat. Hasil diklat diketahui selama proses penyelenggaraan berlangsung melalui mekanisme penilaian yang diatur dalam Perka LAN nomor 13 tahun 2013 dan telah diubah dalam Perka LAN No. 22 Tahun 2014. Penilaian akhir peserta diperoleh melalui nilai pada saat seminar I (perencanaan inovasi) dan seminar II (manajemen perubahan). Indikator dan bobot penilaian setiap seminar menunjukkan kompetensi yang dibangun sesuai tujuan diklat yaitu kompetensi kepemimpinan operasional yang merupakan kemampuan membuat perencanaan kegiatan dan memimpin keberhasilan implementasi pelaksanaan kegiatan tersebut.

Peserta Diklat Kepemimpinan Tingkat IV Angkatan II dengan kualifikasi kelulusan yaitu sebanyak 22 orang atau $73 \%$ termasuk kategori memuaskan dan 8 orang atau $27 \%$ termasuk kategori cukup memuaskan. Peserta diklat angkatan III dengan kualifikasi memuaskan sebanyak 16 orang atau $53 \%$ dan 14 orang atau $47 \%$ mendapatkan kategori cukup memuaskan. Hal tersebut berarti jumlah peserta yang mendapatkan kategori kelulusan memuaskan pada angkatan II dan III adalah sebanyak 38 orang atau $63 \%$ dan kategori cukup memuaskan sebanyak 22 orang atau $37 \%$. Rentang nilai kategori memuaskan adalah antara $>80,00-90,00$, sedangkan kategori cukup memuaskan berada pada antara nilai $>70,00-80,00$.

Inti kompetensi kepemimpinan dalam diklat kepemimpinan adalah membentuk pemimpin perubahan. Filosofi pemimpin perubahan ini diilhami oleh konsep kepemimpinan adaptif (adaptive leadership) yang dikembangkan oleh Heifetz (2009: 14). Adaptive leadership is the practice of mobilizing people to tackle tough challenges and thrive. Kebutuhan perlunya pemimpin adaptif karena adanya tantangan yang kompleks dan tidak cukupnya improvisasi operasional untuk menghadapi tantangan perubahan yang kompleks tersebut. Oleh karena itu, pemimpin perubahan yang dibentuk dalam Diklat Kepemimpinan Tingkat IV adalah pemimpin yang mampu melakukan adaptasi dan inovasi terhadap perubahan yang terjadi di lingkungan organisasi. Perubahan tersebut dilakukan dalam rangka mempertahankan dan mengembangkan organisasi menuju tingkat kinerja yang tinggi sesuai dengan harapan dan visinya.

\section{Evaluasi Perilaku}

Evaluasi perilaku mengukur penggunaan atau penerapan pengetahuan, sikap, dan keterampilan dalam bekerja berdasarkan apa yang diperoleh selama diklat. Hasil kuesioner menunjukkan bahwa 91,67\% peserta menganggap pengetahuan yang diberikan selama diklat kurang bersifat praktis. Ketika hal itu ditanyakan secara langsung, sebagian besar peserta menganggap bahwa mata diklat tersebut semuanya penting dan sangat membantu pelaksanaan tugas di kantor. Setelah dikaji lebih lanjut dengan mengamati tempat tugas dan tugas pokok dari beberapa peserta bahwa wajar ada perbedaan tersebut karena adanya perbedaan persepsi. Beberapa peserta yang bekerja pada instansi teknis menganggap bahwa selama diklat akan mendapatkan pengetahuan teknis sesuai bidang pekerjaannya.

Perubahan perilaku dimaksudkan sebagai akibat dan konsekuensi dari keikutsertaan peserta dalam Diklat Kepemimpinan Tingkat IV sekaligus sebagai bentuk keberhasilan dalam mengikuti 
diklat. Penilaian penerapan perilaku yang diperoleh selama diklat difokuskan pada nilai-nilai integritas, etika publik, kedisiplinan, dan kerja sama. Keempat nilai tersebut menjadi bagian dari penilaian hasil diklat. Perubahan kompetensi perubahan perilaku tersebut lebih bermakna apabila dapat bermanfaat dan mendukung pelaksanaan tugas peserta pada instansinya masing-masing. Hal tersebut diakui oleh peserta diklat dengan penjelasan bahwa mendukung pelaksanaan tugas di eselon IV terutama dalam meningkatkan inovasi kreativitas dan motivasi kerja, mendukung kepastian percepatan kegiatan, ketepatan sasaran kegiatan, serta hasil kegiatan. Terjadi peningkatan bobot kualitas. Adanya kemampuan mengaktualisasikan integritas pribadi terhadap tugas. Mempermudah pelaksanaan tugas-tugas karena ada pengetahuan dan pengalaman dalam melaksanakan koordinasi, konsultasi, dan lainnya.

Penerapan keterampilan di tempat kerja setelah diklat diukur dari keterampilan kepemimpinan oerasional terutama dalam melakukan perubahan pada unit kerjanya. Banyak perubahan yang dilakukan oleh peserta diklat terutama dilihat dari sisi keterampilan kepemimpinan. Keterampilan yang didapatkan selama diklat tentu kurang bermakna jika tidak diterapkan pada unit kerjanya. Pengakuan beberapa peserta mengenai keterampilan yang agak sulit diterapkan diinstansinya adalah keterampilan koordinasi, komunikasi, dan membangun tim yang solid serta efektif. Kesulitan penerapannya sangat bergantung pada jenis tugas dan kemampuan peserta.

\section{Evaluasi Hasil}

Evaluasi hasil mengukur tingkat program diklat telah membantu pencapaian tujuan organisasi yang telah ditetapkan sebelumnya dan berdampak kepada peningkatan kinerja organisasi. Aspek yang dievaluasi pada level hasil diklat adalah mulai dari tujuan diklat dan perannya terhadap kompetensi kepemimpinan, peningkatan kualitas kerja dan hasil kerja, penciptaan iklim kerja, kualitas layanan, dan tingkat kepercayaan masyarakat terhadap organisasi.

Transfer pembelajaran menuju hasil diklat dipengaruhi oleh interaksi kompleksitas beberapa variabel. Terdapat tiga faktor utama yang mempengaruhi kemungkinan tranfer pembelajaran kepada hasil, yaitu; ability to use, motivation to use, and the work environment (Wick, C., Roy P., \& Andrew J., 2010: 176). Kemampuan peserta menerapkan pembelajaran dengan mempertimbangkan: kapasitas peserta membuat perubahan, situasi kerja memberikan kesempatan menerapkan hasil belajar, hasil pembelajaran yang relevan, pemikiran untuk dapat diterapkan. Motivasi menyangkup kepercayaan menerapkan keterampilan baru untuk meningkatkan kinerja, penghargaan atas penerapan keterampilan baru, serta keberterimaan nilai-nilai. Hal lain yang mempengaruhi motivasi adalah kepercayaan diri peserta dan kesiapan berpartisipasi pada diklat. Lingkungan kerja meliputi pengaruh manajer, kelompok sebaya, dan sistem penghargaan.

\section{KESIMPULAN}

Berdasarkan hasil penelitian dan pembahasannya, dapat diambil kesimpulan sebagai berikut: (1) Reaksi peserta diklat terhadap aspek kurikulum, tenaga kediklatan, dan fasilitas diklat berada pada kategori memadai. Kurikulum Diklat sepenuhnya mengacu kepada Perkalan Nomor 13 Tahun 2013 serta telah memenuhi kualitas dan harapan peserta diklat. Hal tersebut tercermin dari penilaian peserta terhadap pengaturan jadwal diklat, pengembangan materi diklat, pengembangan metode pembelajaran, pengembangan media pembelajaran, kegiatan benchmarking ke best practice, dan pelaksanaan laboratorium kepemimpinan. Tenaga kediklatan yang meliputi penyelenggara, widyaiswara, narasumber, coach, dan mentor telah melaksanakan tugasnya dengan baik dan sesuai dengan kriteria dan harapan peserta. Fasilitas diklat cukup memadai dalam mendukung proses penyelenggaraan diklat, mencakup ruang kelas, asrama, sarana pendukung, dan konsumsi. (2) Pembelajaran Diklat Kepemimpinan Tingkat IV untuk meningkatkan kompetensi kepemimpinan operasional telah tercapai. Hal tersebut terlihat dari nilai akhir peserta diklat dengan rata-rata 81,25 dan sesuai kriteria kualifikasi kelulusan peserta diklat berada pada kategori memuaskan. (3) Terjadi perubahan perilaku peserta setelah mengikuti Diklat Kepemimpinan Tingkat IV. Penambahan pengetahuan dan keterampilan serta perubahan sikap perilaku sebagai hasil diklat telah dapat diaplikasikan pada unit kerjanya. (4) Hasil Program Diklat Kepemimpinan Tingkat IV Pemerintah Provinsi NTB Pemenuhan kompetensi bagi peserta diklat terhadap hasil diklat berdampak terhadap peningkatan kinerja instansi khususnya pada aspek pelayanan publik. 


\section{DAFTAR PUSTAKA}

Blanchad, P. Nick \& James W. Thacker. Effective Training: Systems, Strategies, and Practices, Third Edition. New Jersey: Pearson Prentice Hall. 2007.

Flamholtz, Eric and Yvonne Randle. Leading Strategic Change: Bridging Theory and Practice. Newyork: Cambridge University Press. 2008.

Gagne, Robert M., et al. Principles of Instructional Design, Fifth Edition. Belmont: Thomson Wadsworth. 2005.

Heifz, Ronald, A. Grashow, and M. Linsky. The Practice of Adaptive Leadership. Massachusetts: Harvard Business School Publishing. 2009.

Kirkpatrick, D. L \& Kirkpatrick, J.D., Evaluating Training Program, (San Francisco, USA: Berret-Koehler Publisher, Inc. 2005.

,Transfering Learning to Behaviour: Using the Four Level to Improve Performance. Sanfrancisco:: Berret-Koehler Publisher Inc, 2005.

Laird, Dugan. Approaches to Training and Development: New Perspectives in Organizational Learning, Performance, and Change, Cambridge: Perseus Publishing. 2003.

Miles, Matthew B. \& A. Michael Huberman. Analisis Data Kualitatif. terjemahan Tjetjep Rohendi Rohidi. Jakarta: UI-Press. 2009.

Mujiman, Haris. Manajemen Pelatihan Berbasis Belajar Mandiri. Yogyakarta: Pustaka Pelajar. 2011.

Patton, Michael Quinn. Metode Evaluasi Kualitatif, terjemahan Budi Puspo Priyadi. Yogyakarta: Pustaka Pelajar 2009.

Pribadi, Benny P. Desain dan Pengembangan Program Pelatihan Berbasis Kompetensi: Implementasi Model ADDIE. Jakarta: Prenada Media Group. 2014.

Sedarmayanti. Manajemen Sumber Daya Manusia: Reformasi Birokrasi dan Manajemen Pegawai Negeri Sipil. Bandung: Refika Aditama.2013

Sitepu. Penulisan Buku Teks Pelajaran. Bandung: Remaja Rosdakarya. 2012.
Subrahmanian, Mu. "Evaluating Training Programmes in India Post", Researchers World: Journal of Arts Sciences \& Commerce, Vol-I, Issue-1, October 2010.

Suparman, M. Atwi. Desain Instruksional Modern: Panduan Para Pengajar dan Inovator Pendidikan. Jakarta: Erlangga. 2012.

Supranto. Pengukuran Tingkat Kepuasan Pelanggan: untuk Menaikkan Pangsa Pasar. Jakarta: Rineka Cipta. 2011.

Sukardi. Evaluasi Program Pendidikan dan Kepelatihan. Jakarta: Bumi aksara. 2014.

Thoha, M. Chabib. Teknik Evaluasi Pendidikan. Jakarta: PT. RadjaGrafindo Persada. 2003.

Thoha, Miftah, Manajemen Kepegawaian Sipil di Indonesia, Jakarta: Kencana Prenada Media Group, 2005.

Wang, Victor C. X. Assessing and Evaluating Adult Learning in Career and Technical Education. Hershey: Zhejiang University Press. 2011.

Widoyoko, S. Eko Putro. Evaluasi Program Pembelajaran: Panduan Praktis bagi Pendidik dan Calon Pendidik. Yogyakarta: Pustaka Pelajat. 2012. 